\title{
Governance of the Cassurubá Extractive Reserve, Bahia State, Brazil: An analysis of strengths and weaknesses to inform policy
}

\author{
Danieli Marinho Nobre ${ }^{\mathrm{a}, \mathrm{b}, *}$, Daniela Trigueirinho Alarcon ${ }^{\mathrm{c}}$, Ana $\operatorname{Cinti}^{\mathrm{d}}$, Alexandre Schiavetti ${ }^{\mathrm{e}}$ \\ a Programa de Mestrado em Sistemas Aquáticos Tropicais, Universidade Estadual de Santa Cruz (UESC), Rodovia Jorge Amado, Km 16, Bairro Salobrinho, \\ CEP 45662-900, Ilhéus, Bahia, Brazil \\ b Conservação Internacional do Brasil, Rua das Palmeiras, 451, Caravelas, Bahia, Brazil \\ c Pós-doutorado em Zoologia, UESC, Brazil \\ a Centro para el Estudio de Sistemas Marinos (CESIMAR), CCT CENPAT-CONICET, Puerto Madryn, Chubut, Argentina \\ e Departamento de Ciências Agrárias e Ambientais, UESC, Brazil
}

\begin{abstract}
A B S T R A C T
This study analyzed the governance of the Cassurubá Extractive Reserve or RESEX in Bahia State, Brazil, exploring the favorable conditions and the difficulties faced by this newly established and complex governance system. RESEXs are protected areas that involve traditional communities in its administration through majority representation in a Deliberative Council (DC). Research was conducted through literature and documents review, participant observation through direct involvement in community activities along several years (20082016), and semi-structured and structured interviews applied respectively to members of the DC and to users of the RESEX during 2012 and 2013. The Institutional Design Principles were used as an analytical tool to reflect on the strengths, limitations, and the multiple factors affecting its governance. Interview results suggest a more negative perception of resource users about RESEX functioning and prospects than DC members. Participation of resource users in RESEX meetings was low and a passive performance of council members was observed. Since 2012-2013, participation of users and council members has been gradually increasing. Several of the design principles were found to be present (boundaries, congruence, collective arrangements though enhanced participation is needed, conflict resolution mechanisms, recognition of rights to organize, nested enterprises), and only two were deemed insufficient or mostly absent: monitoring (4A and 4B), but improving in terms of community participation in vigilance, and graduated sanctions (5), present in legislation but hardly implemented. Further studies should be pursued for continuing adding blocks to the understanding of CPR governance systems with diverse degrees of complexity.
\end{abstract}

\section{Introduction}

Governance can be defined as the distribution of power, legitimacy, and authority among the diverse levels and institutions involved, in which rules are established regarding who is to be involved, how power is to be shared and decisions made, as well as the degree of coresponsibility to be adopted among participants [3]. The establishment of clear rules to access and use Common Pool Resources or CPRs ${ }^{1}$ (e.g. fish, forests, watersheds) is key to promote resource conservation, and represents a first step to be addressed in any management process so that stakeholders can benefit and realize their interests [1].

Achieving effective governance is critical for Protected Areas to reach their goals [4]. A Marine Protected Area (MPA) can be defined as "a clearly defined geographical space, recognized, dedicated and managed, through legal or other effective means, to achieve the longterm conservation of nature with associated ecosystem services and cultural values" [5]. MPAs quickly become a mainstream management tool for biodiversity conservation in practically all the world's oceans and seas [6]. A growing trend has been observed in MPAs in the last two decades to be employed as fisheries management tool and to diversify objectives, incorporating uses, users and socio-cultural goals [5,7]. In Brazil, MPAs are an important and widespread governance instrument of coastal and marine areas [8].

MPAs typically exert a stronger support from conservation ambits than from the fishing sector [9], and integrating both perspectives poses a major challenge. MPAs generally work through a process involving multiple actors from different sectors, an essential element that adds a challenging dimension to governance [10]. Fisheries and

\footnotetext{
* Corresponding author.

E-mail addresses: danicumuru@hotmail.com (D.M. Nobre), danitabio@hotmail.com (D.T. Alarcon), cinti@cenpat-conicet.gob.ar (A. Cinti), aleschi@uesc.br (A. Schiavetti).

${ }^{1}$ Common Pool Resources are ones for which exclusion from the resource is costly and one person's use subtracts from what is available to others [1].
} 
MPAs management is also and foremost about people management, and their success depends on effectively integrating cultural norms and practices, socioeconomic considerations and diverse interests and perspectives [11].

Several other factors have shown to influence MPA success. For example, from an ecological standpoint, Edgar et al. [12], based on a sample of 87 worldwide MPAs, showed that conservation benefits (species' biomass, abundance, and diversity in MPAs) increase exponentially with the accumulation of five key features (no-take, wellenforced, old ( $>10$ years), large ( $>100 \mathrm{~km} 2$ ), and isolated by deep water or sand). Similarly, in a review of MPA efficacy from an ecological and social standpoint based on 10 MPAs in the Gulf of California, Mexico, MPAs have failed because of insufficient no-take zones, lack of enforcement, poor governance, and minimal community involvement [13]. Institutional (governance) constraints are often times the primary sources of difficulties that affect social and ecological outcomes, being the implementation phase the most challenging one, facing for example: overlapping jurisdictions, conflicts in objectives, incongruent zoning schemes, insufficient investments for administration, monitoring and enforcement; and limited participation of the sectors involved [14-19].

Governance has shown to be crucially dependent on collaboration of multiple social actors across levels and scales of organization [20]. Governance mechanisms which ensure meaningful consultation with the public about design and management are possible and essential to success [15]. Local participation and autonomy may provide management regimes with the necessary flexibility and adaptability to adjust to local and external conditions [21] and increase rule legitimacy for those involved in creating them (likely increasing compliance), as opposed to rules externally imposed.

This study addresses a special type of Protected Area, the Reserva Extrativista (Extractive Reserve) or RESEX, with characteristics of IUCN category VI, with sustainable use of natural resources. RESEXs are innovative PAs that involve traditional communities in their administration through majority representation in a Deliberative Council, and entail a range of objectives: to protect the livelihoods and cultures of these populations, and to ensure the sustainable use of natural resources as well as biodiversity conservation [22]. As the userights are formally granted to local users, RESEXs integrate a variety of groups and participatory management arrangements between the state bodies and the users, which imply new functions for the latter in the form of monitoring, decision-making, and the crafting of rules [23].

On the other hand, RESEXs are institutional arrangements that attempt to address the complexity of natural resources management situations [24], involving various governmental and non-governmental groups with diverse interests, and several CPRs being used or thought to be protected in the same geographic area, representing a major challenge in terms of collective action. Common-pool resources theory was initially constructed on the basis of relatively simple cases, e.g. single CPRs and user groups, placing a strong emphasis on local dynamics $[1,25]$. Nonetheless, the applicability of the theory to more complex situations has been questioned [24,26,27], and has become a field of active research in recent years [15,28-31]. For example, Fleischman et al. [32] analyzed the applicability of the institutional design principles (underlying principles that characterize robust institutions $)^{2}[1,2]$ in five large-scale governance systems, suggesting strong support to some principles and weak support to others; at large scales, other kinds of political dynamics, including the role of scientists and civil society organizations, appear to play key roles.

This study aimed to analyze the governance of the Cassurubá RESEX, Bahia State, Brazil, through exploring key stakeholders'

\footnotetext{
${ }^{2}$ Underlying principles that characterize robust institutions for managing commonpool resources, developed through investigation of long-lasting, self-organized governance systems [25].
}

perceptions about its functioning and prospects, and examining the enabling conditions present and the difficulties faced by this new and ambitious governance system. The Institutional Design Principles (version by [2]) were used as an analytical tool to examine the strengths and weaknesses of this RESEX and to deepen the reflection on the multiple factors affecting its governance. Cox et al. [2] reevaluated the empirical support to the principles after 20 years of their inception and found that their presence is generally associated with favorable collective outcomes. The principles were used as a diagnostic tool, not to predict a good or bad ending (for the intended scope of the principles see [25]). Results are discussed in light of recent developments on the topic.

\section{Study area}

\subsection{The RESEX model}

The RESEX model seeks to reconcile biodiversity conservation, cultural preservation of traditional populations and sustainable use of natural resources [33]. RESEXs originated in the rubber tappers' movement in the Amazonian forests [34] and started to be established in marine areas in the early 1990s. The Act No. 9,985 established the National System of Nature Conservation Units (Sistema Nacional de Unidades de Conservação da Natureza or SNUC) [22], and defines RESEX as: "an area used by traditional populations, which livelihoods are based on the use of natural resources, and complementarily on subsistence agriculture and small cattle ranching, being its basic objectives to protect the livelihoods and the cultures of these populations and to ensure the sustainable use of the natural resources of the unit."

Traditional populations or communities are acknowledged as "culturally differentiated groups that recognize themselves as such and have their own forms of social organization, that occupy and use territories and natural resources as a condition for their cultural, social, religious, ancestral and economic reproduction, using knowledge, innovations, and practices generated and transmitted by tradition" (Decree 6,040 [35],).

To make the traditional population concept operational, the RESEX model requires the definition of a user profile, to be created with community participation. Those categorized as users, who hold the attributes defined in the profile, are entitled to use the RESEX natural resources, including fishery resources. The people defined as users will have access to a contract of use (Concessão de Direito Real de Uso or $\mathrm{CDRU})^{3}$ and will be able to draw up the rules of the Management Plan.

RESEXs are headed by the Instituto Chico Mendes de Conservação da Biodiversidade (Chico Mendes Institute for Biodiversity Conservation) or ICMBio, a governmental environmental agency, and decisions are collectively taken by representatives of the fishing communities and other interested public segments (e.g. other governmental agencies, NGOs, recreational/tourism groups) in a Deliberative Council (DC hereafter) where users have majority representation $(50 \%$ +1 seats). ICMBio administers the PA through a manager who moderates the meetings and accompanies the work of the DC. The manager plays a very important role in the administration of the RESEX, and in cases of tied votes, the ICMBio - through the managertakes the last decision.

\subsection{The Cassurubá RESEX}

The Cassurubá RESEX is located in South Bahia and extends across

\footnotetext{
${ }^{3} \mathrm{CDRU}$ - Document through which the government grants the users the right and the exclusivity to use the resources inside the territory. The concession is for 20 years and renewable.
} 


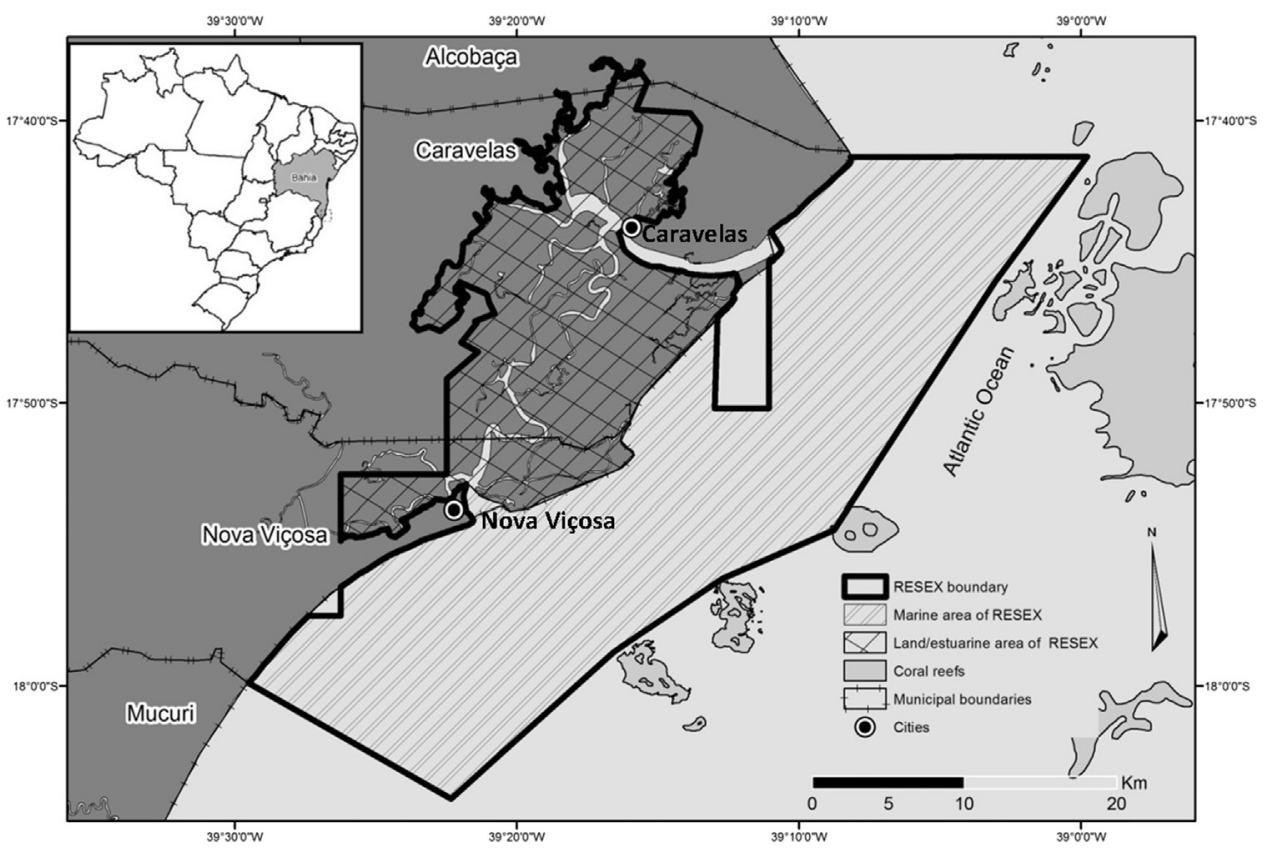

Fig. 1. Location of the Cassurubá RESEX, Bahia State, Brazil. Map credit: Joaquim Rocha dos Santos Neto.

the municipalities of Caravelas, Nova Viçosa, and Alcobaça (Fig. 1), with 100,767 ha in total. The reserve was created in 2009 to prevent the placing of a large shrimp farming undertaking in the area. At the moment there was social mobilization, and some local associations in partnership with NGOs conducted baseline studies and petitioned the creation of the RESEX.

The RESEX is located in the Abrolhos Bank, the most extensive area of the continental shelf that hosts the highest biodiversity of the South Atlantic [36], and which conservation depends on an integrated approach to the coastal environment. The RESEX includes mangroves that are extremely important for the maintenance of coastal ecosystems and critical environments for the reproduction and protection of numerous estuarine and marine species of aquatic fauna [37].

The RESEX comprises oceanic, coastal-marine, and estuarine areas (Fig. 1), and there are diverse fishing modalities depending on the area utilized (Fig. 2):

- In mangrove forests and the estuary, canoes or boats are used for the manual gathering of oysters (Crassostrea mangle), clams (Lucina pectinata), red mangrove crab (Goniopsis cruentata), uçá crabs (Ucides cordatus) and blue land crab (Cardisoma guanhumi), mussels and others; fishing is also done with lines, nets, and camboas (a type of enclosure net).

- At sea, small vessels up to $7 \mathrm{~m}$ long are used. Shrimp fishing (Xiphopenaeus kroyeri) with bottom-trawling nets and line fishing for fish species (Lutjanidae and Carangidae families mostly) are the most common species and gears.

About 300 families live inside the RESEX and benefit from the easy access to natural resources. They are distributed especially in riverine zones. Another 2000 families that live in urban areas outside the RESEX boundaries also use resources from inside the reserve.

The DC of the Cassurubá RESEX was created in 2012 and consists of 27 representatives, including three members of governmental agencies, nine members of the organized civil society, and 15 representatives of fishing communities (see Table A1). DC members are elected by their constituents; however they do not necessarily belong to an organized association. At the DC, decisions have to be made in accordance with federal laws. The bylaw (internal rules) of the DC was approved in the same year, with the aim to provide the members specific rules to guide DC decisions and procedures. The management of the Cassurubá RESEX is thus shared among the component institutions.

Since its creation, the DC has elaborated a Fisheries Agreement (or Acordo de Pesca), which contains the agreed rules and management measures adopted for a fishery or a species, aiming at sustainability. The Fisheries Agreement is an instrument similar to a Management Plan (MP), although not as comprehensive, which only applies to the marine area of the RESEX [38]. The MP is yet to be finalized (as of December 2016) and was hence inexistent at the moment of data collection.

\section{Methods}

The methodology included literature and documents review, participant observation (since RESEX creation up to 2016), and structured and semi-structured interviews applied, respectively, to members of the DC and to users of the Cassurubá RESEX between September 2012 and September 2013. The review included academic texts, newspaper and magazine articles, official documents (laws, bylaws), and minutes of DC meetings. The questionnaire applied to DC members had 30 questions on the following topics: identification of respondents, their knowledge of RESEX management instruments, perceptions about RESEX organization and performance, and degree of satisfaction on certain governance aspects. The Likert scale [39] was used in questions that assessed levels of satisfaction. The questionnaire was meant to be applied to all DC members ( $\mathrm{N}=27)$, but only 23 were finally interviewed because of some absences during the data collection phase. Data was analyzed in a descriptive manner. Interviews were transcribed and responses analyzed using Microsoft Excel 2010.

The perception of the users of the Cassurubá RESEX was collected through semi-structured interviews applied to 81 individuals, attempting to cover the diversity of fishing gears and species used in the area, and the proportion of fishers working in each major environment (sea and estuary). Although the number of individuals that work in each environment is unavailable, the number of families that reside in cities and work at sea is known to be significantly larger (2000) than the people who reside and fish in rivers and estuaries (300 families). Fishers from 12 communities were interviewed (eight riverine communities and four urban communities). Most of respondents (84\%) 


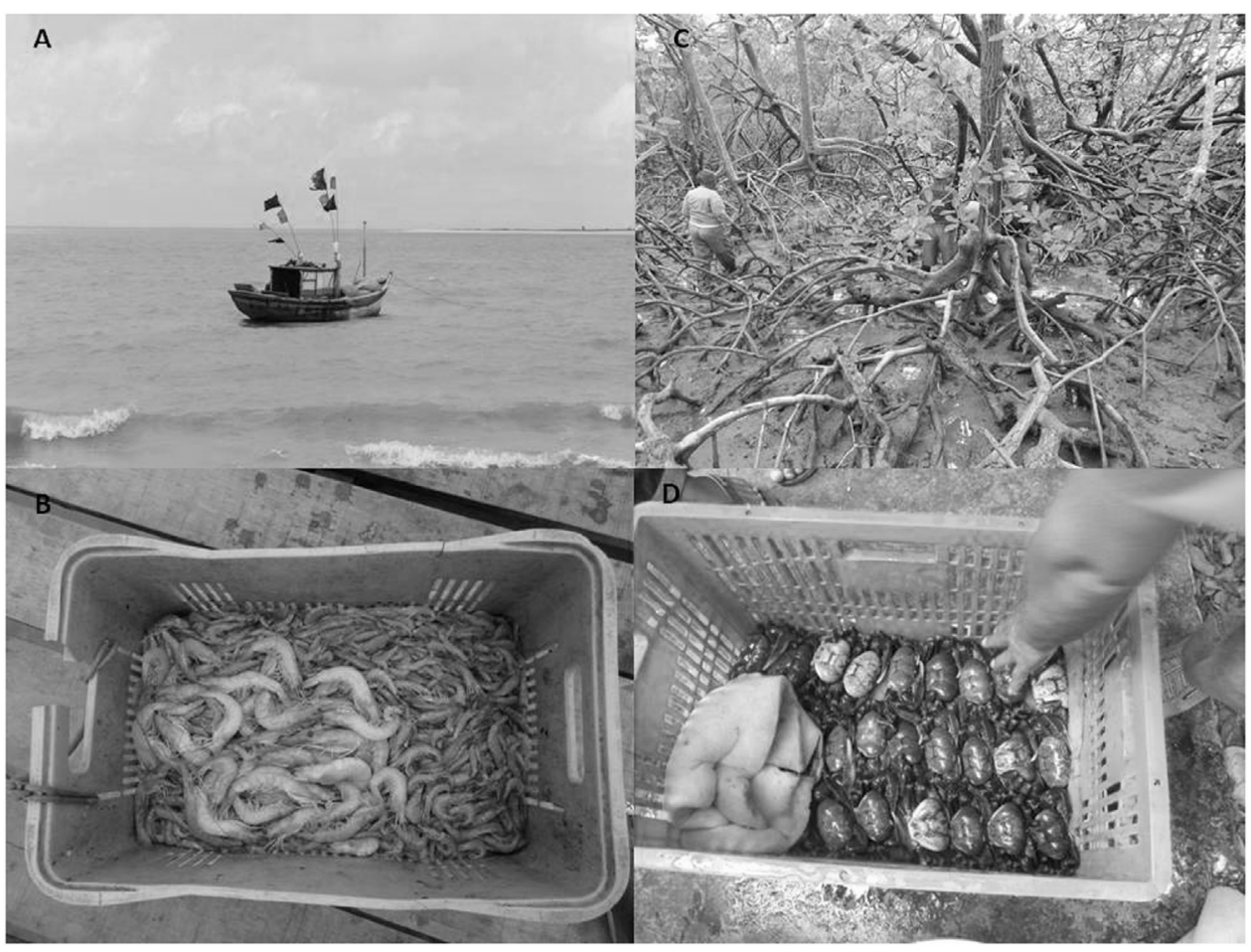

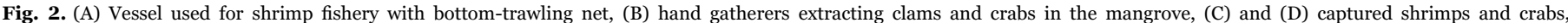
respectively. Photographs credit: Danieli Nobre (A, C and D), Vanessa Santana (B).

were from urban communities that work at sea. The interview addressed their knowledge about and acceptance of the RESEX, their expectations regarding the reserve, and the changes perceived since the creation of the reserve. Data obtained from open-ended questions was categorized and frequencies of mentions were estimated. Although categorization of open-ended questions is not recommended [40], frequencies were estimated to have a sense of the strength of users' spontaneous responses to the questions; however, percentages should not be interpreted as representative of the population. Participant observation was conducted during all DC meetings up to mid-2016 (16 council meetings since RESEX creation), in addition to field visits and some meetings of local community associations. Besides, the first author of this work participated directly in the process of creation of the RESEX, through dissemination of information and community mobilization as a member of a local NGO and as resident of Caravelas (a town inside the RESEX, Fig. 1) since 2008.

To analyze the presence of the institutional design principles [1], the version proposed by Cox et al. [2] was used (Table 1). The content of each principle was based on literature and documents review, and participant observation. As most of the topics addressed in the interviews relate to issues that fall within the scope of the principles, interview results were also included in their description. Since several interview questions related to the functioning of the Deliberative Council, the core formal decision making body, principle 3 will be disproportionate in length compared to other principles.

\section{Results}

\subsection{The design principles at the Cassurubá RESEX}

In what follows, the major changes occurred in terms of the design principles with the creation of the RESEX are described (Table 1).

\subsubsection{Principle 1: clearly defined user (1A) and resource (1B) boundaries}

This principle states that the boundaries of the resource system and the individuals or households with rights to harvest resource units must be clearly defined. Principle $1 \mathrm{~A}$ "enables participants to know who is in (who will benefit) and who is out of a defined set of relationships, and thus, with whom to cooperate" (addresses the freeriding problem) [25]. Clear resource boundaries (1B) enable the group to reinforce their rights (against others) and to more effectively monitor resource condition and social behavior.

Before the RESEX was created there were no limits defined in terms of allowed users and physical boundaries, the area was open to public use and without exclusivity in favor of traditional populations (Table 1). After the RESEX, the definition of "users" - those who will be entitled to use reserve natural resources among other benefits-was not yet materialized at the time of interviews but the process was developing. The granting of access rights to the RESEX natural resources require registration in a cadastral list at ICMBio, elaborated progressively in subsequent meetings and workshops held at the communities and then voted for at the DC (Table 1). The user profile of the RESEX was approved in a DC meeting in June 2016 (minutes approved in November 2016) but it has not been published yet at the official diary (is not yet effective). The user profile approved at the DC establishes several requirements, being the place of birth the most important. The individual who was born in the area covered by the RESEX or in the municipalities that intersect with the area, and resides in any of these municipalities, can be categorized as beneficiary (user) if, in addition to this criterion, comply with one of the following requisites:

1. to depend on traditional fishing or shellfish gathering activities using traditional techniques inside the RESEX territory;

2. to depend on handicraft activities, collection of seeds and fruits, family farming, animal husbandry or activities related to community-based tourism, practiced inside the RESEX;

3. to depend on the mangroves, forests and seas, and to live in a traditional way.

In addition, there was consent in that the children of beneficiary 
Table 1

Institutional design principles (after [Cox et al., 2010], before and after the establishment of the Cassurubá RESEX.

\begin{tabular}{|c|c|c|}
\hline Principles & Before RESEX & After RESEX \\
\hline 1. Clearly defined boundaries & $\begin{array}{l}\text { Open access. Without demarcation of the area or } \\
\text { the users. }\end{array}$ & $\begin{array}{l}\text { Access only permitted to local users, excluding } \\
\text { "outsiders". Area formally defined. }\end{array}$ \\
\hline \multicolumn{3}{|l|}{$\begin{array}{l}\text { 1A. Individuals or households who have rights to withdraw } \\
\text { resource units from the common-pool resource (CPR) must } \\
\text { be clearly defined. }\end{array}$} \\
\hline \multicolumn{3}{|l|}{ 1B. The boundaries of the CPR must be well defined. } \\
\hline $\begin{array}{l}\text { 2. Congruence between appropriation and provision rules and } \\
\text { local conditions }\end{array}$ & $\begin{array}{l}\text { Top-down rules, created without local participation, } \\
\text { not matching local conditions. }\end{array}$ & $\begin{array}{l}\text { Specific rules created with local people, based on local } \\
\text { conditions, although having to conform to higher } \\
\text { hierarchy Federal laws. }\end{array}$ \\
\hline \multicolumn{3}{|l|}{$\begin{array}{l}\text { 2A. Appropriation rules restricting time, place, technology, and/ } \\
\text { or quantity of resource units are related to local conditions. }\end{array}$} \\
\hline \multicolumn{3}{|l|}{$\begin{array}{l}\text { 2B. The benefits obtained by users from a CPR, as determined by } \\
\text { appropriation rules, are proportional to the amount of inputs } \\
\text { required in the form of labor, material, or money, as } \\
\text { determined by provision rules. }\end{array}$} \\
\hline 3. Collective-choice arrangements & Individuals affected by the rules could not directly & Through the DC (collective decision making arena), \\
\hline $\begin{array}{l}\text { Most individuals affected by the operational rules can } \\
\text { participate in modifying the operational rules. }\end{array}$ & participate in modifying them. & $\begin{array}{l}\text { the individuals affected can participate in the creation } \\
\text { and modification of rules. }\end{array}$ \\
\hline 4. Monitoring & $\begin{array}{l}\text { Without regular monitoring of resources or users } \\
\text { behavior. Intermittent monitoring of some fishery } \\
\text { resources via NGOs. Lack of enforcement. }\end{array}$ & $\begin{array}{l}\text { Without significant changes, although planned (need } \\
\text { implementation). }\end{array}$ \\
\hline \multicolumn{3}{|l|}{$\begin{array}{l}\text { 4A. Monitors are present and actively audit CPR conditions and } \\
\text { appropriator behavior. }\end{array}$} \\
\hline \multicolumn{3}{|l|}{$\begin{array}{l}\text { 4B. Monitoring: Monitors are accountable to or are the } \\
\text { appropriators. }\end{array}$} \\
\hline 5. Graduated sanctions & $\begin{array}{l}\text { Users who violated national rules were notified and } \\
\text { non-compliance could result in fines and seizures. } \\
\text { Graduated sanctions, although poorly implemented. }\end{array}$ & $\begin{array}{l}\text { Without significant changes, although planned (need } \\
\text { implementation). }\end{array}$ \\
\hline \multicolumn{3}{|l|}{$\begin{array}{l}\text { Appropriators who violate operational rules are likely to be } \\
\text { assessed graduated sanctions (depending on the seriousness } \\
\text { and context of the offense) by other appropriators, officials } \\
\text { accountable to these appropriators, or both. }\end{array}$} \\
\hline 6. Conflict-resolution mechanisms & $\begin{array}{l}\text { Informally in schools and other public places, } \\
\text { without formal forums. }\end{array}$ & $\begin{array}{l}\text { In addition to informal means, there is room for } \\
\text { conflict resolution at the DC. }\end{array}$ \\
\hline \multicolumn{3}{|l|}{$\begin{array}{l}\text { Appropriators and their officials have rapid access to low-cost } \\
\text { local arenas to resolve conflicts among appropriators or } \\
\text { between appropriators and officials. }\end{array}$} \\
\hline 7. Minimal recognition of rights to organize & $\begin{array}{l}\text { Local rules unrecognized by government } \\
\text { authorities. Without exclusive use rights granted in } \\
\text { favor of local residents. }\end{array}$ & $\begin{array}{l}\text { Government recognition and long-term use-rights (to } \\
\text { be formalized). }\end{array}$ \\
\hline \multicolumn{3}{|l|}{$\begin{array}{l}\text { The rights of appropriators to devise their own institutions are } \\
\text { not challenged by external governmental authorities. }\end{array}$} \\
\hline 8. Nested enterprises & $\begin{array}{l}\text { Activities organized by several government } \\
\text { institutions, without direct local participation. }\end{array}$ & $\begin{array}{l}\text { Activities organized by several government } \\
\text { institutions but with an intermediate level of } \\
\text { coordination, with more ample and direct local } \\
\text { participation. }\end{array}$ \\
\hline $\begin{array}{l}\text { Appropriation, provision, monitoring, enforcement, conflict } \\
\text { resolution, and governance activities are organized in } \\
\text { multiple layers of nested enterprises. }\end{array}$ & & \\
\hline
\end{tabular}

families (direct descendants) that leave the area of the RESEX and return afterwards will become beneficiaries automatically. In the case of families that are not originally from the municipalities that intersect with the RESEX but were established in the area prior to the creation of the RESEX (June 2009), they will be considered beneficiaries as long as they depend on the same traditional activities that characterize this profile. There is also a special case which does not relate to ancestry or traditional practices and includes the providers of services (e.g. health and education) who work and reside in the communities inside the RESEX. In order to become beneficiaries, they must work and reside for a period of minimum 5 consecutive years. The DC also contemplates the possibility of evaluating other special cases. New entrances or exists will have to be treated at the DC.

The physical limits of the Cassurubá RESEX are legally defined in legislation, although community members exhibit different levels of understanding regarding such limits.
4.1.2. Principle 2: congruence between benefits (appropriation rules) and costs (provision rules) and local conditions

This principle states that the harvesting rules (restricting time, place, technology, and/or quantity of resource units) and the rules to maintain productive activities (regulating inputs required in the form of labor, material, or money) must be congruent (2B) and tailored to local conditions (2 A) $[2,25]$. Otherwise, costs that exceed benefits and/ or an unfair distribution of costs and benefits among participants may negatively affect cooperation and outcomes. Likewise, unadjusted rules might not be considered legitimate or useful, likely affecting compliance and outcomes.

Before the RESEX there were only general norms for fishery resources like reproductive closures valid for the State of Bahia (decided at the Federal level). The RESEX changed meaningfully the way in which decisions are made, giving the communities a more prominent role than previously (Table 1). The Management Plan (MP) of the Cassurubá RESEX, which defines rules of use, zoning and other measures related to the management of the reserve, is currently in its final phase (as of December 2016). The elaboration of the MP of the 
Cassurubá Resex began at the end of 2015. Several stages comprise the elaboration of this document [41]: the definition of a ICMBio planning team; the creation of a working group linked to the DC (with council member and community members) that will accompany all MP stages; the systematization of existing information about the RESEX; and the conduction of community meetings to elaborate specific rules for the use of the RESEX resources. In these community meetings, participants must select a person that will represent the community in a General Assembly (the final stage of the MP) in which all communities involved in the RESEX will discuss and define the rules of use of the RESEX fishery resources. The elaboration of the MP is hence led by ICMBio and the DC, but participation extends beyond these ambits. Except for the Assembly, which is scheduled for the first half of 2017, all other steps have been completed at the Cassurubá RESEX. This process should ensure greater congruence between rules and local conditions (Table 1).

In the meanwhile, there is another formal instrument in force, The Fisheries Agreement of the Marine Area of 2013 (see [38]) that contains rules for the management of the RESEX. This agreement was a first and important achievement involving decisions made collectively by the representatives of the communities and other public segments at the DC. It reflects the local conditions, and can be modified over time. For instance, in one occasion there were some fishers catching shrimp during the ban period, using a net that was only authorized for capturing fish. This issue was brought to the DC by the fishing sector and the use of that net was forbidden for any species (neither fish nor shrimp) during the shrimp ban period, becoming an official regulation. This somewhat severe decision was jointly taken because of the existing deficiencies in enforcement and to reduce the fishing pressure over shrimp, a species of high importance for local fishers that is also key food item for other commercially important species of fish, thus benefiting several groups of fishers. This is an example of a low-cost rule that, if efficiently implemented, can provide tangible benefits for the users and resource stocks. The presence of informal harvesting and access rules was not identified, but community workshops (to define the user profile and the management plan) would probably incorporate at least some customary codes, practices, and knowledge; this topic however requires in depth exploration.

On the other hand, the perception of the users about the RESEX collected through interviews (users'acceptance, expectations and perceived changes), also reflects perceived benefits and costs (as determined by rules) beyond just fishery resources (main CPR in the area). Concerning the acceptance of the RESEX, only $28 \%$ of respondents had a positive opinion, with prevailing percentages belonging to less positive categories (26\% against the RESEX and $15 \%$ unaware of its existence) or to respondents lacking an opinion (31\%) (Table 2). The fact that some respondents were unaware of the existence of the reserve could be due to the recent creation of the RESEX and the limited number of employees to communicate reserve news and actions. The main motives against the RESEX included increased restrictions on the sale of properties ${ }^{4}$ and the breeding of large animals [22], wood removal and some agricultural practices in areas inside the RESEX (clearing land is prohibited [42];). Most of these restrictions are in Federal legislation applying to all Conservation Units (local term for Protected Areas) in the country; they cannot be modified locally. Conflicts for overlap of fishing zones between fishers from Alcobaça and Nova Viçosa (Fig. 1), two fishing communities that fish inside the RESEX, were mentioned as negative consequences of the RESEX.

\footnotetext{
${ }^{4}$ In relation to the sale of properties, after obtaining the contract of use or CDRU, all RESEX territory covered by the contract will belong to the Union (Federal State) and land owners with land title who are not beneficiaries (unrecognized users) will be expropriated and indemnified. There will be no restriction for beneficiaries (recognized users) who want to sell improvements (houses, plantations or productions) to other beneficiaries, but the land will always belong to the Union. Beneficiaries will not be able to sell improvements to non-beneficiaries.
}

Table 2

Users' responses regarding acceptance of the RESEX, expectations regarding the future of fishing and the RESEX, and perceived changes since RESEX creation $(n=81)$.

\begin{tabular}{lll}
\hline Theme & Response category & \% of respondents \\
\hline $\begin{array}{l}\text { Acceptance of the } \\
\text { RESEX }\end{array}$ & Users favorable to the RESEX & 28 \\
& & 31 \\
& Users indifferent to the RESEX & 26 \\
& Users against the RESEX & 15 \\
& Users unaware of the existence of \\
the RESEX & 15 \\
& $\begin{array}{l}\text { Users pessimistic regarding the } \\
\text { future of fishing and/or the RESEX }\end{array}$ & 67 \\
& $\begin{array}{l}\text { Users indecisive about the future of } \\
\text { fishing and/or the RESEX }\end{array}$ & 17 \\
& $\begin{array}{l}\text { Users neutral regarding the future } \\
\text { of fishing and/or the RESEX } \\
\text { Users optimistic about the future of } \\
\text { fishing and/or the RESEX }\end{array}$ & 7 \\
& $\begin{array}{l}\text { Did not perceive changes since } \\
\text { RESEX creation } \\
\text { Did perceive changes since RESEX } \\
\text { creation }\end{array}$ & 83 \\
\hline
\end{tabular}

In terms of expectations regarding the future of fishing and the RESEX, most respondents provided answers about the future of fishing, or combined fishing and the RESEX on a single answer (as expected given the question formulated). Responses were combined and considered as the "future of fishing and/or the RESEX". The majority of respondents revealed pessimism (67\%), and only $7 \%$ had an optimistic view (Table 2).

In terms of perceived changes since RESEX creation, the great majority of respondents (83\%) did not perceive any changes, neither positive nor negative (Table 2). Of the $17 \%$ that did perceive changes, 9\% mentioned the prohibition on the selling of properties located inside the RESEX, $4 \%$ the prohibition on the breeding of large animals, wood removal for domestic use and some agricultural practices; $1 \%$ the restrictions on fishing zones, gears and species; and 1\% the requirement that fishers participate in surveillance, all with negative connotation. Only $2 \%$ of respondents mentioned positive changes that included an increase in enforcement (1\%) and the exclusion of fishers from outside the region (1\%).

In summary, opportunities for adjusting rules to local conditions have been created and are underway, mostly in the case of fishery resources. Users' perceptions suggest low acceptance, poor expectations and no significant changes as of 2012-2013, probably due to the recent creation of the RESEX (2009) and the elaboration of the Fisheries Agreement at about the same moment of interviews.

\subsubsection{Principle 3: collective choice arrangements}

This principle states that most individuals affected by a resource regime should be authorized to participate in making and modifying their rules [25]: "Resource regimes that use this principle are better able to tailor rules to local circumstances and to devise rules that are considered fair by participants". This principle is closely related to principle 2 and 7.

Several opportunities for collective discussion and decisions have been created with the RESEX, being the Deliberative Council (DC) the primary and most comprehensive forum with deliberative and informative character. Bottom-up management of the RESEX is enabled by the existence of the DC, as the final decisions concerning the management of the reserve are largely made by the members of this council. The resolutions voted at the DC are taken by ICMBio and if they are in accordance with Federal laws, they become effective. Each community segment has associations that must represent them, which meet more or less regularly. The Associação Mãe da RESEX Cassurubá or 
AMREC, is an umbrella association that congregates the associations and fishery segments of the Cassurubá RESEX. It is named as associação mãe (mother association) because it includes the representatives of all the users associations of the RESEX. AMREC was created in 2013 with the goal of fomenting interaction between communities and for guiding their collective performance at the DC. Unfortunately, it has not yet reached its goal. In spite of this, the representatives of users associations participate directly at the DC. Examples of products of collective action carried out in the context of the DC with substantial communities' participation are the Fisheries Agreement and the Management Plan (to be finalized in 2017).

Besides the DC, there are also -more informal- forums for discussion and for setting agreements at the community level, which feed upper -more formal- levels of decision making. Also, themes of particular interest to specific communities are handled within the affected community, via associations and community spaces, thus having some degree of autonomy in deciding local issues.

In addition to the above, interviews explored DC members' knowledge and satisfaction regarding governance aspects, which speaks about the functioning of the council as of 2012-2013.

\subsubsection{Knowledge and perceptions of DC members about} management instruments and governance aspects.

DC members were asked about the management instruments that they recognize and consider important for RESEX management (closed-ended question, categories offered: Management Plan (MP), DC, Fisheries Agreement, Other(s)): 46\% of respondents identified the DC as a key management instrument, followed by $27 \%$ of respondents that recognized the MP and other 27\% acknowledged the Fisheries Agreement. This suggests a more generalized recognition of the role of the DC in RESEX administration.

Regarding the status of existing management instruments (closedended question, categories offered: inexistent, in preparation and in operation): $73 \%$ of respondents stated that the MP was in preparation, and $27 \%$ asserted that it did not exist. Since the MP started to be elaborated in 2015, two years after the interviews, it is possible that those who thought that the MP was in preparation have interpreted the Fisheries Agreement as a previous step of the MP. Regarding the area of application of the Fisheries Agreement, all respondents recognized that the current agreement covers solely the marine region of the RESEX, indicating that DC members are clear on this respect.

To have a sense of respondents experience with RESEX history and processes, their participation in RESEX creation was assessed: $82 \%$ of respondents declared to have participated in the creation of the RESEX, and the rest did not participate, possibly because some institutions may have integrated the council later on after RESEX creation or due to the replacement of representative members. Nonetheless, the percentage of members with long history in the RESEX is considerably high.

For an effective representation, the representatives of communities and other public sectors inside the DC should take their demands to the DC and, when deciding, follow the will of their constituents. DC members were asked whether the constituents (users of resources and other DC public sectors) have a voice inside the council and $100 \%$ responded that they do (as expected given their role). Eighty percent of respondents declared that they always share information and decisions discussed at the DC with their constituents and $20 \%$ that they share them sometimes. In terms of the frequency of meetings with constituencies: $40 \%$ of respondents declared not to arrange frequent meetings with their constituents, and $60 \%$ declared to meet at least thrice a year. It was observed that the frequency of meetings was lower among representatives of fishing communities and their constituencies (resource users) compared to other DC sectors. Consequently, specific issues that could be solved within communities are often taken to the

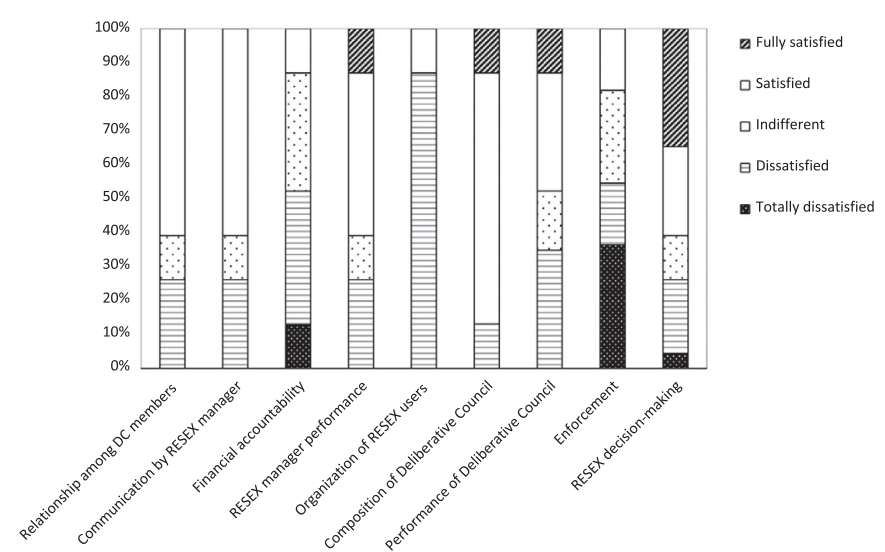

Fig. 3. Percentage of satisfaction of respondents (DC members) regarding governance aspects.

DC, burdening the council agenda and weakening communities' rights to deal with their own issues. Also, this suggests limitations in the level of information obtained and the feedback provided by resource users during council meetings.

\subsubsection{Satisfaction of DC members regarding governance aspects (5} points Likert-scale).

Council members were asked about their satisfaction about specific governance aspects of the Cassurubá RESEX (Fig. 3). In terms of the relationship among DC members involved in RESEX management, $61 \%$ of respondents were satisfied (against about 25\% dissatisfied) (Fig. 3), suggesting a moderately cooperative environment.

A demand frequently expressed by DC members during council meetings relates to the effectiveness of the RESEX manager in communicating decisions and actions taken by ICMBio regarding the reserve. Sixty one percent of respondents were satisfied with the current transference of information (against about 25\% dissatisfied) (Fig. 3).

During the elaboration of the DC bylaw, it was jointly decided not to inform the financial accountability of the reserve at the council meetings. In spite of this joint decision, most respondents were unhappy when they were denied access to financial information (39\% dissatisfied and $13 \%$ fully dissatisfied) or indifferent (neither satisfied nor dissatisfied) (35\%) (Fig. 3); only about 10\% expressed satisfaction.

As for the performance of the RESEX manager concerning the execution of his duties, there is moderately high satisfaction $(48 \%$ satisfied and $13 \%$ fully satisfied, against $25 \%$ dissatisfied), which may be due to the arrival of one more analyst to the team, a recent (as of 2012-2013) improvement in equipment and human resources for surveillance (boat, fuel, and a sailor), and the fact that the current manager was a native of Caravelas (Fig. 1). The latter may have a positive side, being the manager friendly with DC members, but could also induce bias for obtaining information or for expressing their true feelings about the manager to the interviewer.

In terms of the organization of RESEX users, the great majority of DC members were dissatisfied (87\%). Even though the DC is a space for discussion open to everyone (not only to representatives), it has been observed that users still show little interest in participating in this important space. This may be due to their low associative organization, lower education and empowerment, and insufficient support from the partners (mainly government agencies).

With regards to the composition of the council, the great majority of respondents expressed satisfaction ( $74 \%$ satisfied and $13 \%$ fully satisfied). This result can be attributed to the fact that the council is mostly composed of community representatives, and the percentage of dissatisfaction -albeit low (13\%)- to the low participation of the state 
government and other segments of the community.

In terms of the performance of the council, responses were slightly skewed towards positive categories, with $48 \%$ of positive opinions (grouping the satisfied and fully satisfied categories) and a $35 \%$ expressing dissatisfaction. Efforts to achieve a more effective performance were implemented since 2014. For example, technical committees dedicated to specific tasks have been created, which increase the responsibilities of DC members to assign roles and follow-up progress, but at the same time reduces the work load of DC members themselves and activates participation in the process.

Lastly, with regards to decision-making at the council, more than $60 \%$ of DC members had a positive opinion, with $35 \%$ being fully satisfied.

Information gathered through participant observation suggests that participation of resource users in DC or other RESEX meetings was low as of 2012-2013. Fishers have become more interested and involved in reserve issues in the last few years. At the time of interviews there was also a sort of disempowered participation of representatives at the DC. For example, since the DC is led by a manager, the council members tended to take a rather passive performance, transferring the responsibility of executing decisions to the managing entity (ICMBio). Fortunately, council members have progressively enhanced their participation along the years.

In summary, the formal mechanisms for participation in decision making are in place and the exercise of participation, although still scarce, has been gradually improving.

\subsubsection{Principles 4: monitoring}

This principle states that in long-lived governance systems, monitors are present and actively audit CPR conditions and appropriator behavior (4A), and monitors are accountable to or are the appropriators (4B) [2].

Regular monitoring of resource condition and of extractive activities (e.g. fishery monitoring) has been insufficient since the creation of the RESEX (almost nonexistent before). Some monitoring initiatives have arisen via local NGOs and Universities to monitor fishery resources, although focusing on a few species and areas, and during relatively short periods. Government led monitoring efforts are mostly applied during closure periods for species of high economic value (e.g. shrimp).

Monitoring of users behavior can only be performed by competent authorities, mainly ICMBio, which has limited infrastructure and human resources, and hence limited capacity for enforcement. The manager of the RESEX (ICMBio staff) is the person in charge of enforcement, which is accountable to ICMBio authorities higher up. Resource users can collaborate with enforcement by doing their part (following rules) and through filing complaints against offenders, as they lack the authority to punish and control. The need for increased and periodic enforcement has been a demand genuinely claimed by council members and resource users since the creation of the RESEX. At the time of interviews (2012-2013) thirty five percent of DC members were totally dissatisfied with current enforcement (in addition to $17 \%$ dissatisfied) and only $17 \%$ expressed satisfaction. Satisfaction is mainly related to a reduction in the entry of fishers from outside the region into the RESEX area, and the greater dissemination of information about restrictions and sanctions to discourage possible offenders.

Recent initiatives indicate a positive change in the direction of increased user participation in vigilance. In 2015 and 2016, a group of fishers participated in the pilot implementation of a monitoring program of rule conformance at the reserve during the reproductive closures of shrimp and sea bass (to be implemented in the crab fishery in 2017), in which the fishers participate as informants, without capacity to sanction. This program was inspired by a voluntary environmental monitoring program for indigenous people (Programa de Agente Ambiental Voluntário Indígena) implemented by IBAMA ${ }^{5}$ (Brasilean Institute of the Environment and Renewable Natural Resources) that used to aid enforcement efforts in Protected Areas (in force between 2005-2013) [43,44]. Although the monitoring program implemented at Cassurubá is not yet backed up by any legislation, it has been successful, increasing the number of complaints and encouraging local people to act and participate ([45], page 126).

\subsubsection{Principles 5: graduated sanctions}

Graduated sanctions help to maintain community cohesion while genuinely punishing severe cases [2]. This principle states that there should be proportionality between the severity of the violation and the sanctions. At Cassurubá, current sanctions are based on fines and seizures, and are aggravated if the infraction is more serious. Since enforcement is limited, the application of sanctions is also limited.

\subsubsection{Principle 6: conflict resolution mechanisms}

Principle 6 points to the importance of access to rapid, low-cost, local arenas to resolve conflict among users or among users and officials [25]. Before and after the RESEX, segments of the communities had the opportunity to discuss their conflicts in an informal manner. Despite not having assembly halls, people are used to sit in open spaces like schools, backyards, squares, and discuss about issues affecting their communities. Prior to the creation of the RESEX there was local organization through associations, but the RESEX increased the motivation of the people to organize and to participate in community discussions and in the formal forums created with the RESEX.

The DC is an important space to mediate and solve conflicts in which general as well as highly conflictive issues concerning the reserve may be discussed. The council meetings generally have an overloaded agenda and the frequency of meetings is low (should meet three times a year minimum according to the bylaw), but important conflicts have been addressed (between 2014-2016): for example, adjustments to the operation of motorized boats, which used fishing areas traditionally used by canoe fishers. Through the DC, canoe fishers claimed and obtained an exclusive space, ought to be respected by other fishers. In addition, the DC has conquered specific benefits to support the fishers; as a consequence, the fishers are becoming more organized and have obtained important benefits for common use such as an ice factory and headquarters for associations.

\subsubsection{Principle 7: minimal recognition of rights to organize}

This principle states that the rights of users to devise their own rules should not be challenged by external governmental authorities; at least minimal recognition should be given to the legitimacy of locally developed rules [1]. This author argued that lack of recognition of local rights to organize creates conflicts between customary and federal rules and within the community, as harvesters attempt to circumvent local traditions by appealing to federal rules (cited in [46]). This design principle also expresses that "users (should) have long-term tenure rights to the resource" [1].

After the RESEX, communities gained rights to devise their own rules through their seats at the Deliberative Council in which fishing communities have majority representation. The rules approved at the council, albeit having to pass through complex and slow administrative processes, generally have a strong bottom-up component (see principles $1-3$ ). The rules approved at the council ought to be recognized by federal, state and municipal governments, provided that they conform to preexisting laws and regulations.

The RESEX model itself provides greater recognition and legitimacy to community concerns as explicitly stated in its objectives: "to protect the livelihoods and the cultures of traditional populations and

\footnotetext{
${ }^{5}$ Stands for Instituto Brasileiro do Meio Ambiente e dos Recursos Naturais Renováveis.
} 
to ensure the sustainable use of the natural resources of the unit". Tenure security is granted through exclusive and long-term use-rights to resource users through a contract of use or CDRU. This contract lasts 20 years and can be renewed. At Cassurubá, the contract has not been signed yet (as of December 2016) but it is in the process to be formalized.

The contract is signed between ICMBio and the mother association or AMREC (Associação Mãe da RESEX Cassurubá), represented by its president. AMREC is the umbrella association that is supposed to congregate the associations and fishery segments of the Cassurubá RESEX. Although AMREC is not very active right now, the signature of the contract with this association seeks to favor all associations that make up the RESEX.

\subsubsection{Principle 8: nested enterprises}

Principle 8 states that in large CPRs, governance activities are organized in multiple layers of nested enterprises [1]. The Cassurubá RESEX was created by federal decree and thus there are agencies responsible for issues that directly influence reserve activities and organization. It involves various levels of governance: municipal, state, and federal; it is regulated by federal legislation (SNUC and Decree no. 4340) [22] and managed by the DC with representation of those three levels of government among several other segments (e.g. users' associations, NGOs, recreational/tourism representatives).

Even though RESEXs are institutional arrangements which premise is ample participation in decision making, in practice reserves are part of a broader system that exerts a direct influence on their functioning and performance. For example, the DC as well as the municipal and State levels, can only create more restrictive and compatible rules than existing Federal laws.

In addition, the RESEX is jointly managed among many and diverse institutions. Inter-connectedness is highly necessary given the RESEX design and objectives. In spite of current limitations, it can be said that several coordinated actions are occurring, operated by the various institutions at different levels. The Deliberative Council serves as a forum to integrate information and perspectives coming from diverse sectors and levels (communities, regional, federal), to define rules and actions considering -to some degree- particularities of all levels.

\section{Discussion}

This study analyzed the governance of the Cassurubá RESEX, which despite its recent creation (2009), shows several advancements in the application of management instruments compared to other RESEXs with longer time of creation at the Bahia State. The implementation of a RESEX is a new reality that needs an adaptation phase. Although many of its goals has yet to be materialized, the Cassurubá RESEX has achieved an enhanced social organization, a Deliberative Council (DC) in operation and a Fisheries Agreement being implemented, and a gradual increase in social participation in decision making. It has also attained a reduction in the competition for resources by "outsiders" (other small-scale fishing communities) and the exclusion of industrial fleets, and protection against large "development" projects (i.e. real estate, ports, oil) or large-scale shrimp farming; the latter being the threat that triggered the creation of this RESEX. However, important deficits remain, including lack of infrastructure, human and financial resources, especially for enforcement and monitoring of resources and activities to ensure that RESEX objectives are met, and an incipient level of stakeholders' participation in decision making, particularly poor in the case of resource users.

Therefore, several of the institutional design principles were found to be present at the Cassurubá RESEX (boundaries, congruence, collective arrangements though enhanced participation is needed, conflict resolution mechanisms, recognition of rights to organize, nested enterprises), and only two were deemed insufficient or mostly absent: monitoring (4 A and 4B), but improving in terms of community participation in vigilance in a few sites, and graduated sanctions (5), which is present in legislation but hardly implemented.

The literature on design principle makes a strong call to the notion that configurations of design principles are necessary for success $[1,25,32,47]$. Baggio et al. [47] analyzed the co-ocurrence of design principles by activity (fishery, irrigation and forestry) and the combinations of design principles leading to social and ecological success (sample of 69 cases). These authors found that congruence between local conditions and rules (2 A) and proportionality between investment (costs) and extraction (benefits) (2B) are key attributes for CPR success independent from the type of resource. These two subprinciples are rarely present in cases where CPR management is not successful. In addition, the authors also suggest that high co-ocurrence between collective choice arrangements (principle 3) and rights to organize (principle 7) can be evidence of the feedback between governments and resource-using communities, feedback that has been acknowledged as highly important for effective governance [7,26,4850]. But interactions between stakeholders are also instances of shared knowledge that promotes congruence (principle 2). Rules that are congruent with local social and ecological conditions are often the product of collective-choice arrangements [1]. For example, in cases of collaborative fisheries management, partnerships between scientists, fishers and other stakeholders often provide effective channels through which two-way cross-fertilization between experience-based and research-based knowledge develops as a result [51]. In the same line, Barnett and Anderies [46] (cited in [47]) have suggested that "the absence of these two principles ( 3 \& 7) may weaken the congruence between rules and local social and ecological conditions".

Our case study also suggests a close relationship between principle 2 (congruence), 3 (collective choice arrangements) and 7 (recognition of rights to organize). Congruence is augmented or has the chances to be enhanced by the possibility of sharing visions, information, decisions and actions among diverse stakeholders, created through the establishment of collective decision making arenas that generate partnerships (i.e. a Deliberative Council where fishers have a prominent role). These collective spaces for decision making are highly enriched by the presence of groups or communities of users with sufficient autonomy to organize and provide feedback, which particularities are recognized by higher up authorities (with authority to some extent devolved). Security of tenure is provided by the RESEX system (once the contract has been formalized), which has been found to be a crucial aspect for sustainable natural resource-use [1,7,52]. The three principles (2, 3 and 7) are present at the Cassurubá RESEX; however, participation is still incipient and needs to be substantially enhanced.

On the other hand, Baggio et al. [47] also highlights that the absence of principles $2 \mathrm{~A}, 2 \mathrm{~B}, 4 \mathrm{~B}$ (presence of monitors accountable to users) and 5 (graduated sanctions) seems to increase the odds of a nonsuccessful CPR system. At Cassurubá, monitoring of resources and social behavior is weak. Graduated sanctions exist on paper; implementation is poor due to weak enforcement. Even though monitors are accountable to higher up authorities, community participation in vigilance is increasing in at least in some sites of the RESEX. Monitoring is a key aspect of the RESEX that needs to be considerably enhanced.

In more complex governance systems, like coastal MPAs or larger systems (e.g. oceanic fisheries), recent publications that dealt with CPR theory suggest similarities and some differences with relatively simpler governance settings. For example, Fleischman et al. [32] analyzed the applicability of the design principles in five large-scale governance systems of CPRs: national forests management in Indonesia, the Great Barrier Reef Marine Park in Australia, mitigation of trans-boundary water pollution in the Rhine River in western Europe, international protection of the Ozone layer (i.e. the Montreal Protocol), and management of the Atlantic Bluefin Tuna (i.e. the International Convention on the Conservation of Atlantic Tuna), and suggested strong support to some principles (boundaries, monitoring, sanctions, fit to conditions, 
and conflict resolution mechanisms) and weak support to others (recognition of rights to organize and the accountability of monitors to resource users). The authors propose that at large scales, other kinds of factors like political dynamics, the role of scientists and civil society organizations, appear to play key roles. For instance, civil society organizations were crucial in promoting monitoring, sanctioning, and rule-making in several cases, and political dynamics compensated to some extent for the absence of collective-choice arrangements and influenced the proportionality of costs and benefits in others. Also, they assert that bottom-up self-organization may be difficult or impossible to achieve in large-scale systems, and thus other dynamics may be necessary.

The above cases differ from the Cassurubá RESEX first of all in the size of the system addressed; just focusing on the size of the area involved, the Cassurubá RESEX covers an area two orders of magnitude smaller than several of the Fleischman et al. [32] cases (e.g. 100,767 ha the RESEX vs. 34,500,000 ha the Great Barrier Reef Marine Park). Secondly, the objective of the governance system (the RESEX model) is distinct, with priority focus on communities of users and their relationship to the environment in which they dwell, which may explain the observed differences. This objective has guided its institutional design, emphasizing bottom-up construction, embracing the values reflected in the design principles 7 and 3. Nonetheless, RESEXs are Protected Areas with characteristics of IUCN category VI. The fact that an area is declared as protected area introduces by itself institutional rigidity and confers a predominant role to the State (government agencies) in its administration, as observed in several Latin American cases of MPAs that intersect with small-scale fisheries, positing a barrier for self-governance [Cinti et al. in preparation]. The RESEX model is not an exception, showing for example, externally designed and somewhat inflexible administrative processes, and an overemphasis on scientific knowledge with little room for local forms of knowing and doing (see [53]). This author draws attention to interventions by international donor agencies (e.g. the World Bank) that introduced major changes to the initial conception of the RESEX model in which local knowledge and fishing communities were to be further prioritized [53,54]. Even so, RESEXs are more likely to augment communities fundamental rights (not just the rights to use resources) compared to several other MPA formats present in the region [23], [Cinti et al. in preparation].

Studies that explored the applicability of CPR theory in Marine Protected Areas of comparable complexity to the one addressed in this study suggest consistency with theory. For example, Mascia [28] tested the design principles in a comparative case study analysis of Wider Caribbean MPAs (Exuma Cays Land and Sea Park, Bahamas; Barbados Marine Reserve, Barbados; Hol Chan Marine Reserve, Belize) and found that clear boundaries, well-defined resource use rights, accountable monitoring and enforcement systems, graduated sanctions, accessible conflict resolution mechanisms, and user-governance rights were correlated with positive social and ecological outcomes. Christie and White [15] asserted that "field research involving thousands of interviews in the Philippines, Indonesia and West Pacific Island states suggests that fair and effective law enforcement [55], knowledge of the law [56], and consistency between national and local laws and institutional goals [14,57], are important to MPA effectiveness and sustainability"; these issues relate mostly to design principles 4 (A \& B), 2 (A \& B), and 8. Cinti et al. [58] assessed the conditions for sustainability in a Mexican MPA (the Bahía de los Ángeles, Canales de
Ballenas y de Salsipuedes Biosphere Reserve), and found that in spite of showing many of the critical enabling conditions for sustainability on the commons and self-governance [26,27] present (e.g. clearly defined group and resource boundaries; ease of enforcement of rules due to community isolation, small user group size, shared norms), the presence of unsecure tenure rights, poor or null participation of fishers in decision and rule making, a lack of government recognition of local fishery arrangements, and a lack of government support for enforcement, critically affected fisheries and MPA sustainability; these issues relate mostly to design principles 2 (A \& B), 3, 4 (A \& B) and 7. Further research is needed to analyze the applicability of CPR theory to coastal marine Protected Areas in the Latin American Region and globally.

Lastly, with regards to the design principle 7, it is our impression that long-term tenure rights to the resource, a central enabling condition for sustainability, is not very much emphasized or described in recent literature that explicitly deals with the design principles. In line with the distinctions made by Cox et al. [2], who further distilled specific aspects within some of the eight design principles proposed by Ostrom [1], here it is made the suggestion to further specifying this aspect when principle 7 is assessed. This suggestion is based on the observation that recognition not necessarily implies full delegation of rights or control over resources in the long-term or over other more fundamental matters (historical rights restored to communities of traditional users or indigenous peoples) (see [23] for a gradient of rights delegated in Latin American fishery cases).

It is expected that the results presented in this study provide useful lessons for local managers and other participants and contribute to improve the governance of the Cassurubá RESEX. Further studies should be pursued for continuing adding blocks to the understanding of CPR governance systems with diverse degrees of complexity.

\section{Acknowledgments}

Consent for this research was given by the Research Ethics Committee at Universidade Estadual de Santa Cruz (UESC) and the Authorization and Information System on Biodiversity (SisbioICMBio). We specially thank the members of the Deliberative Council and the fishers of the Cassurubá RESEX, who kindly participated in this research. We thank Joaquim Rocha dos Santos Neto for his assistance with Fig. 1, and Vanessa Santana for the photograph. We thank the Graduate Programs in Tropical Aquatic Systems and Development and Environment at UESC, the Coordenação de Aperfeiçoamento de Pessoal de Nível Superior (CAPES), Programa Ciências do Mar, for the fellowship support to the first two authors, and the Conselho Nacional de Desenvolvimento Científico e Tecnológico (CNPq) for the fellowship granted to the last author (Processes 304809/2013-6). We acknowledge the support of The Rufford Small Grants Foundation (11240-1-A. Cinti) and a visiting scholar grant provided by CAPES to the project "Formação de Recursos Humanos para a Concepção, Consolidação, Gestão de Políticas Públicas de Conservação e Manejo de Recursos Renováveis e Áreas Marinhas Protegidas" (UFF-UESC-CENPAT, coordinator R. Kant de Lima), which supported the visit of the third author to the Cassurubá RESEX in 2012, in which the collaboration among the co-authors started to be envisioned. IDEA WILD provided equipment for exploratory research during this visit.

\section{Appendix A:}


Table A1

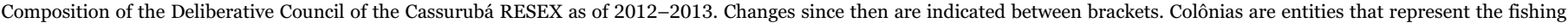
sector in a given region, with larger spatial representativeness than local associations.

Representation of traditional extractive communities

Representation of public sectors and organized civil society (acting or interested in the RESEX)

1. BARRA VELHA I

2. BARRA VELHA II (actual: 1 \& 2 were unified, they have one seat)

1. PREFEITURA MUNICIPAL DE CARAVELAS (MUNICIPAL GOVERNMENT)

3. PEROBAS, TELHAS, TRIBAÚNA E BOM JARDIM

C

3. CENTRO NACIONAL DE PESOUISA E CONSERVAÇÃO DA BIODIVERSIDADE

MARINHA DO NORDESTE (CEPENE) (FEDERAL GOVERMENT)

4. CARIBÊ DE CIMA, C. DO MEIO, C. DE BAIXO, MARTINS, TUCUNZEIRO E 4. BAHIA PESCA (STATE GOVERNMENT)

LARGO

5. CARIBÊ DE CIMA, C. DO MEIO, C. DE BAIXO, MARTINS, TUCUNZEIRO E LARGO (actual: 4 \& 5 were unified, they have one seat)

6. MACACO, LOPES, JABURUNA, MASSANGANO

7. CASSURUBÁ

8. TAPERA, MIRINGABA E RIO DO POÇO

9. ASSOCIAÇÃO DE MARISQUEIRAS E PESCADORES DE NOVA VIÇOSAASMAP

10. CALABOUÇO E CUPIDO

11. ASSOCIAÇÃO DE MARISQUEIROS E PESCADORES DE PONTA DE AREIA -AMPAC

12. ASSOCIAÇÃO DOS PESCADORES E MARISQUEIRAS DA BARRA DE CARAVELAS

13. COLÔNIA Z-29 (ENTITY THAT REPRESENTS THE FISHING SECTOR)

14. COLÔNIA Z-24 (ENTITY THAT REPRESENTS THE FISHING SECTOR)

15. APESCA/ COLÔNIA Z-25 (ENTITY THAT REPRESENTS THE FISHING SECTOR)

5. EMPRESA BAIANA DE DESENVOLVIMENTO AGRÍCOLA (EBDA) (actual: no longer acting in the region)

6. SINDICATO DOS TRABALHADORES RURAIS - CARAVELAS (actual: was moved to the group of representatives of traditional extractive communities)

7. INTERNATIONAL CONSERVATION-BRASIL / INSTITUTO BALEIA JUBARTE - IBJ. (NGO)

8. ARTE MANHA/ ECOMAR (NGO)

9. ASSOCIAÇ̃̃O DOS PRODUTORES DE FLORESTA PLANTADA DO ESTADO DA BAHIA ABAF (FIBRIA/ SUZANO)

10. INSTITUTO CHICO MENDES DE CONSERVAÇÃO DA BIODIVERSIDADE - ICMBIO (FEDERAL GOVERMENT)

11. CÂMARA DE VEREADORES DE CARAVELAS (MUNICIPAL CHAMBER)

12. INSTITUTO DO MEIO AMBIENTE E RECURSOS HÍDRICOS DO ESTADO DA BAHIA INEMA/SEMA (STATE GOVERNMENT)

\section{References}

[1] E. Ostrom, Governing the Commons: The Evolution of Institutions for Collective Action, Cambridge University Press, Cambridge, 1990.

[2] M. Cox, G. Arnold, S.V. Tomás, A review of design principles for community-based natural resource management, Ecol. Soc. 15 (4) (2010) (article38) 〈http://www. ecologyandsociety.org/vol15/iss4/art38/>.

[3] M. Grindle, Good enough governance: poverty reduction and reform in developing countries, Governance 17 (2004) 525-548. http://dx.doi.org/10.1111/j.09521895.2004.00256.x

[4] P. Dearden, M. Bennett, Trends in global protected areas governance, 1992-2002, Environ. Manag. 36 (2005) 89-100. http://dx.doi.org/10.1007/s00267-004-01319.

[5] J. Day, N. Dudley, M. Hockings, G. Holmes, D. Laffoley, S. Stolton, S. Wells, Guidelines for applying the IUCN protected area management categories to marine protected areas, IUCN, Gland, Switz. (2012) 36.

[6] T. Agardy, P. Bridgewater, M.P. Crosby, J. Day, P.K. Dayton, R. Kenchington, D. Laffoley, P. McConney, P.A. Murray, J.E. Parks, L. Peau, Dangerous targets? Unresolved issues and ideological clashes around marine protected areas, Aquat. Conserv. Mar. Freshw. Ecosys. 13 (2003) 353-367. http://dx.doi.org/10.1002/ aqc.583.

[7] FAO, Report and documentation of the Expert Workshop on Marine Protected Areas and Fisheries Management: Review of Issues and Considerations, Rome, 1214 June 2006, FAO FisheriesReport No. 825, Rome, FAO, 2007, p. 332.

[8] H.S. Macedo, M. Vivacquab, H.C.L. Rodrigues, L.C. Gerhardingerd, Governing wide coastal-marine protected territories: a governance analysis of the Baleia Franca Environmental Protection Area in South Brazil, Mar. Pol. 41 (2013) 118-125. http://dx.doi.org/10.1016/j.marpol.2013.01.008.

[9] P.J.S. Jones, Point of View - Arguments for conventional fisheries management and against no-take marine protected areas: only half of the story?, Rev. Fish. Biol. Fish. 17 (2007) 31-43. http://dx.doi.org/10.1007/s11160-006-9016-8.

[10] P.J.S. Jones, W. Qiu, E.M. De Santo. Governing marine protected areas: getting the balance right, Technical report 2011 United Nations Environment Programme Nairobi.

[11] M. Chadwick, S. Nichols, Summary and recommendations, In: Science and local knowledge: Making the linkages work in Canada's MPAs,Université de Moncton, 2002, pp. 32-33.

[12] G.J. Edgar, R.D. Stuart-Smith, T.J. Willis, S. Kininmonth, S.C. Baker, S. Banks, N.S. Barrett, M.A. Becerro, A.T.F. Bernard, J. Berkhout, C.D. Buxton, S.J. Campbell, A.T. Cooper, M. Davey, S.C. Edgar, G. Forsterra, D.E. Galvan A.J. Irigoyen, D.J. Kushner, R. Moura, P.E. Parnell, N.T. Shears, G. Soler, E.M.A. Strain, R.J. Thomson, Global conservation outcomes depend on marine protected areas with five key features, Nature 506 (2014) 216-220. http:// dx.doi.org/10.1038/nature13022.

[13] A.N. Rife, B. Erisman, A. Sanchez, O. Aburto-Oropeza, When good intentions are not enough. Insights on networks of "paper park" marine protected areas, Conserv.

Lett. 6 (2013) 200-212.

[14] R.V. Eisma, P. Christie, M. Hershman, Legal issues affecting sustainability of integrated coastal management in the Philippines, Ocean Coast. Manag. 48 (2005) 336-359.

[15] P. Christie, A.T. White, Best Practices in Governance and Enforcement of Marine Protected Areas: An overview, in: Report and Documentation of the Expert Workshop on Marine Protected Areas and Fisheries Management: Review of Issues and Considerations, Rome, 12-14 June 2006, FAO FisheriesReport No. 825, Rome, FAO, 2007, p. 332.

[16] B.D. Mapstone, L.R. Little, A.E. Punt, C.R. Davies, A.D.M. Smith, F. Pantuse, A.D. McDonald, A.J. Williamsg, A. Jonesh, Management strategy evaluation for line fishing in the Great Barrier Reef: balancing conservation and multi-sector fishery objectives, Fish. Res. 94 (2008) 315-329.

[17] W. Qiu, B. Wang, P.J.S. Jones, J.C. Axmacher, Challenges in developing China's marine protected area system, Mar. Pol. 33 (2009) 599-605.

[18] M. Glaser, W. Baitoningsih, S.C.A. Ferse, M. Neil, R. Deswandi, Whose sustainability? Top-down participation and emergent rules in marine protected area management in Indonesia, Mar. Pol. 34 (2010) 1215-1225.

[19] J.N. Kittinger, K.N. Duin, B.A. Wilcox, Commercial fishing, conservation and compatibility in the Northwestern Hawaiian Islands, Mar. Pol. 34 (2010) 208-217.

[20] D.R. Armitage, D. Johnson, Can resilience be reconciled with globalization and the increasingly complex conditions of resource degradation in Asian coastal regions?, Ecol. Soc. 11 (1) (2006) (article 2) 〈http://www.ecologyandsociety.org/vol11/iss1/ art $2 /\rangle$.

[21] F. Berkes, J. Colding, C. Folke, Navigating social-ecological systems: building resilience for complexity and change, Cambridge University Press, Cambridge, U.K 2003.

[22] BRASIL, Lei No 9.985, Lei do Sistema Nacional de Unidades de Conservação da Natureza (SNUC)〈http://www.planalto.gov.br/ccivil_03/LEIS/L9985.htm〉, 2000.

[23] J.M. Orensanz, A. Cinti, A.M. Parma, L. Burotto, S. Espinosa-Guerrero, E. SosaCordero, C. Sepúlveda, V. Toral-Granda, Latin-American rights-based fisheries targeting sedentary resources (Paper No. 582), in: J.M. Orensanz, J.C. Seijo (Eds.), Rights-based Management in Latin American Fisheries, FAO Fisheries and Aquaculture Technical, Rome, 2013.

[24] F. Berkes, From community-based resource management to complex systems, Ecol. Soc. 11 (2006) (article45) 〈http://www.ecologyandsociety.org/vol11/iss1/art45/〉.

[25] E. Ostrom, Understanding Institutional Diversity, Princeton University Press, Princeton, NJ, 2005.

[26] A. Agrawal, Common property institutions and sustainable governance of resources, World Dev. 29 (10) (2001) 1649-1672. http://dx.doi.org/10.1016/S0305750X(01)00063-8.

[27] E. Ostrom, A general framework for analyzing, Sustain. Soc.-Ecol. Syst., Sci. 325 (2009) 419-422. http://dx.doi.org/10.1126/science.1172133.

[28] M.B. Mascia, Institutional Emergence, Evolution, and Performance in Complex Common Pool Resource Systems: marine protected areas in the Wider Caribbean (Ph.D. dissertation), Duke University Durham, NC, 2000.

[29] M. Cox, Understanding large social-ecological systems: introducing the SESMAD project, IJC 8 (2) (2014) 265-276.

[30] G. Epstein, M. Nenadovic, A. Boustany, Into the deep blue sea: commons theory 
and international governance of Atlantic Bluefin Tuna, IJC 8 (2) (2014) 277-303.

[31] L.S. Evans, N.C. Ban, M. Schoon, M. Nenadovic, Keeping the 'Great' in the Great Barrier Reef: large-scale governance of the Great Barrier Reef Marine Park, IJC 8 (2) (2014) 396-427.

[32] F.D. Fleischman, N.C. Ban, L.S. Evans, G. Epstein, G. Garcia-Lopez, S. VillamayorTomas, Governing large-scale social-ecological systems: Lessons from five cases, IJC 8 (2) (2014) 428-456. http://dx.doi.org/10.18352/ijc.416.

[33] R. Ganem, Conservação da biodiversidade: legislação e políticas públicas,EdiçõesCâmara, Câmara dos Deputados, Brasília (2010) 437.

[34] P. Chamy, Reservas Extrativistas Marinhas como instrumento de reconhecimento do direito consuetudinário de pescadores artesanais brasileiros sobre territórios de uso comum (in), The Tenth Biennial Conference of the International Association for the Study of Common Property (IASCP), Oaxaca, Mexico, 2004.

[35] BRASIL, Decreto $\mathrm{N}^{\circ} 6.040$, Institui a Política Nacional de Desenvolvimento Sustentável dos Povos e Comunidades Tradicionais $\langle$ http://www.planalto.gov.br/ ccivil_03/_ato2007-2010/2007/decreto/d6040.htm), 2007.

[36] T.B. Werner, L.P. Pinto, P.G.P. Pereira, Abrolhos 2000: conserving the Southern Atlantic's richest coastal biodiversity into the next century, Coast. Manag. 28 (2000) 99-108. http://dx.doi.org/10.1080/089207500263684.

[37] G.B. Marchioro, M.A. Nunes, G.F. Dutra, R.L. Moura, P.G.P. Pereira, Avaliação dos impactos da exploração e produção de hidrocarbonetos no Banco dos Abrolhos e adjacências, Megadiversidade, Belo Horiz. 1 (2005) 225-310.

[38] D.M. Nobre, A. Schiavetti, Acordos de Pesca, Governança e Conselho Deliberativo de Reserva Extrativista: Caso da Resex de Cassurubá, Caravelas, Bahia 39, Boletim do Instituto de Pesca, Brasil, 2013, pp. 445-455.

[39] S.C.Vergara, Métodos de Coleta de Dados no Campo, Editora Atlas, São Paulo, 2009.

[40] L. Hay, Qualitative research methods in human geography, Oxford University Press, Oxford, U.K., and New York, New York, USA, 2005.

[41] ICMBio, Instrução Normativa $\mathrm{N}^{\circ} 01$, Disciplina as diretrizes, normas e procedimentos para a elaboração de Plano de Manejo Participativo de Unidade de Conservação Federal das categorias Reserva Extrativista e Reserva de Desenvolvimento Sustentável/http://www.icmbio.gov.br/portal/images/stories/ imgs-unidades-coservacao/in012007.pdf , 2007.

[42] BRASIL, Lei $\mathrm{N}^{\circ} 11.428$, Dispõe sobre a utilização e proteção da vegetação nativa do Bioma Mata Atlântica, e dá outras providências $\langle$ http://www.planalto.gov.br/ccivil_ 03/_ato2004-2006/2006/lei/l11428.htm), 2006

[43] IBAMA, Instrução Normativa $\mathrm{N}^{\circ}$ 66http://www.icmbio.gov.br/cepsul/images/ stories/legislacao/Instrucao_normativa/2005/in_ibama_66_2005_programasagentesambientaisvoluntarios.pdfcria o programa de agentes, 2005.

[44] IBAMA, Instrução Normativa $\mathrm{N}^{\circ} 09 \mathrm{http}$ ://www.icmbio.gov.br/cepsul/images/ stories/legislacao/Instrucao normativa/2013/in_ibama_09 2013 revoga in ibama_66_2013_agentesambientaisvoluntarios.pdf, 2013.
[45] ICMBio, Revista BOAS PRÁTICAS NA GESTÃO DE UNIDADES DE CONSERVAÇÃO, EDIÇÃO 02http://www.icmbio.gov.br/portal/images/stories/ comunicacao/publicacoes/revista_boas_pratica_2016.pdf, 2016.

[46] A.J. Barnett, J.M. Anderies, Weak feedbacks, governance mismatches, and the robustness of social-ecological systems: an analysis of the Southwest Nova Scotia lobster fishery with comparison to Maine, Ecol. Soc. 19 (4) (2014). http:// dx.doi.org/10.5751/ES-06714-190439.

[47] J.A. Baggio, A.J. Barnett, I. Perez-Ibara, U. Brady, E. Ratajczyk, N. Rollins, C. Rubiños, H.C. Shin, D.J. Yu, R. Aggarwal, J.M. Anderies, M.A. Janssen, Explaining success and failure in the Commons: the configural nature of Ostrom's institutional design principles, IJC 10 (2) (2016) 417-439. http://dx.doi.org/ 10.18352/ijc.634.

[48] S. Jentoft, B. McCay, User participation in fisheries management. Lessons drawn from international experiences, Mar. Pol. 19 (1995) 227-246.

[49] R.S. Pomeroy, F. Berkes, Two to tango: the role of government in fisheries comanagement,, Mar. Pol. 21 (1997) 465-480.

[50] National Research Council, The Drama of the Commons, Washington, DC, 2002.

[51] J.M. Orensanz, A.M. Parma, A. Cinti, Methods to use fisher's knowledge for fisheries assessment and management (Technical Paper No. 591), in: J. Fischer, J. Jorgensen, H. Josupeit, D. Kalikoski, C.M. Lucas (Eds.), Fisher's Knowledge and the Ecosystem Approach to Fisheries, FAO Fisheries and Aquacuculture, Rome, 2015, p. 278.

[52] A. Pagdee, Y. Kim, P.J. Daugherty, What makes community forest management successful: a meta-study from community forests throughout the world, Soc. Nat. Resour. 19 (1) (2006) 33-52.

[53] R. Lobão, Cosmologias políticas do neocolonialismo: como uma política pública pode se transformar em uma política do ressentimento, (Doctoral Dissertation), Universidade de Brasília, Brazil, 2006, p. 313.

[54] T.C. Maranhão, Significados da Pactuação entre Órgãos Públicos Ambientais e Populações Tradicionais, (Doctoral Dissertation), Universidade Federal Fluminense, Niterói, Brazil, 2012, p. 100.

[55] R.B. Pollnac, R.S. Pomeroy, Factors affecting the long-term sustainability of integrated coastal management projects in the Philippines and Indonesia, Ocean Coast. Manag. (2005) 233-251.

[56] World Bank, Voices from the Village: A Comparative Study of Coastal Resource Management in the Pacific Islands, Pacific Islands Discussion Paper Series number 9, Washington DC, 1999.

[57] K. Lowry, A.T. White, C. Courtney, National and local agency roles in integrated coastal management in the Philippines, Ocean Coast. Manag. 48 (2005) 314-335.

[58] A. Cinti, J.N. Duberstein, E. Torreblanca, M. Moreno-Báez, Overfishing drivers and opportunities for recovery in small-scale fisheries of the Midriff Islands Region, Gulf of California, Mexico: the roles of land and sea institutions in fisheries sustainability, Ecol. Soc. 19 (2014). http://dx.doi.org/10.5751/ES-05570-190115. 